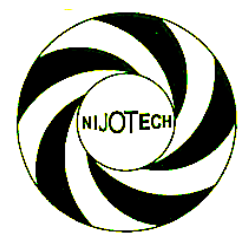

Nigerian Journal of Technology (NIJOTECH)

Vol. 39, No. 3, July 2020, pp. 701 - 709

Copyright@ Faculty of Engineering, University of Nigeria, Nsukka,

Print ISSN: 0331-8443, Electronic ISSN: 2467-8821

www.nijotech.com

http://dx.doi.org/10.4314/njt.v39i3.8

\title{
CHARACTERISTICS OF ALMOND LEAF-ASH CEMENT STABILIZED LATERITIC SOIL
}

\author{
D. B. Eme ${ }^{1, *}$ and K. E. Ohwerhi ${ }^{2}$

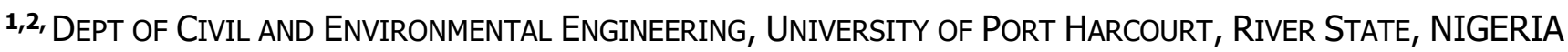 \\ Email addresses; 1 dennis.eme@uniport.edu.ng, ${ }^{2}$ kellyohwerhi@gmail.com
}

\begin{abstract}
The use of Almond leaf-ash for stabilization purposes has not been given consideration. This paper was thus aimed at evaluating the characteristics of almond leaf-ash for the essence of stabilizing lateritic soil. Sourced lateritic soil was divided into 3 components (unmodified soil sample, cement stabilized soil sample and almond leaf-ash cement stabilized soil sample). Almond leaves were calcined at $250^{\circ} \mathrm{C}$ and subjected to granulation process. Preliminary tests such as; sieve analysis, Atterberg's limit and specific gravity tests were done on the unmodified soil sample for the purpose of classification. CBR tests were performed on the cement stabilized soil sample and on the almond leaf-ash cement stabilized lateritic soil sample. A model was developed using the Scheffe's simplex theory with the cement component fixed at $10 \%$ of the dry lateritic soil. Results revealed that the soil was observed to be a Silty Clay soil (A-4) with Plasticity index of $9.24 \%$, therefore requiring stabilization. CBR results for the developed trial mixes were greater than the $15.20 \%$ obtained for $10 \%$ cement stabilization showing that Almond leaf-ash significantly improved the CBR of the cement stabilized lateritic soil. The CBR model developed for the Almond leaf-ash cement soil also proved adequate from the verification test conducted using $X^{2}$ statistics.
\end{abstract}

Keywords: Almond Leaf Ash, stabilization, California Bearing Ratio, Scheffe's theory, lateritic soil.

\section{INTRODUCTION}

Lateritic soils are widely used as fill materials for various construction works in most tropical countries such as Nigeria, where they are in abundance. Lateritic soils are products of tropical weathering with, reddishbrown or dark brown colour, with or without nodules or concretions and generally (but not exclusively) found below hardened ferruginous crusts [1]. These soils are weathered under conditions of high temperatures and humidity and well defined alternating wet and dry seasons resulting in poor engineering properties such as high plasticity, poor workability, low strength, high permeability, tendency to retain moisture and high natural moisture content. For any soil to be utilized for Civil Engineering works, there is need for investigation to enable the engineers use the soil economically, to predict their engineering properties and their performance under field conditions, with a fairly good degree of accuracy. Negligence on the part of construction engineers have led to uncountable road and structure failure within the Sub-Sahara Africa. Lateritic soil consists of high plastic clay, the plasticity of the soil may result to cracks and damage on pavement, roadways, building foundations or any civil engineering construction project ([2]); [3]).

The need to improve the strength and durability of lateritic soil in recent times has become imperative; this has geared researchers towards using stabilizing materials that can be sourced at a very low cost [4]. Various geotechnical tests have been carried out over the past few years using different materials such as quick and hydrated lime [5], oil palm fronds ash [2], egg shell powder [6], bitumen emulsion and cement combination [7] to mention but a few stabilizers. It was revealed from these studies, that lateritic soils are graded with deficiency in sand and silt size particles. The result of the findings from the different researches showed that addition of stabilizers increased the strength or has negligible effect. There are different methods of soil stabilization; ([8]; [9]) noted from their study that with mechanical stabilization, the

\footnotetext{
* Corresponding author, tel: +234-805-594-3566
} 
particle size distribution constituting the material is not affected, but its structure is changed because the particles are redistributed.

[10] investigated the effects of bagasse ash on compaction and strength characteristics of cement stabilized lateritic soil and also to develop geometric models. The compaction, California bearing ratio, unconfined compressive strength and durability tests were carried out on the cement-stabilized soil. Constant cement contents of $2 \%, 4 \%, 6 \%$ and $8 \%$ with variations of bagasse ash from $0 \%$ to $20 \%$ at $2 \%$ intervals and all percentages used were by the weight of dry soil. Result from their showed that the strength properties of the lateritic soil increased with baggash ash addition. [11] collected laterite soil from Maikunkele area of Minna, classified as an A-7-6 on AASHTO classification, was stabilized with $2-8 \%$ cement by weight of the dry soil. Using British Standard Light (BSL) compaction energy, the effect of Rice Husk Ash (RHA) on the soil was investigated with respect to compaction characteristics, California Bearing Ratio (CBR) and Unconfined Compressive Strength (UCS) tests. Results obtained, indicate a general decrease in Maximum Dry Density (MDD) and increase in Optimum Moisture Content (OMC), all with increase in RHA Content (2-8\%) at specified cement contents. There was also a tremendous improvement in the CBR and UCS with increase in the RHA content at specified cement contents to their peak values at between $4-6 \%$ RHA. The UCS values also improved with curing age. This indicates the potentials of using 4-6\% RHA admixed with less cement contents for laterite soil stabilization. [12] carried out an investigation of the potential of stabilizing an expansive clay soil with the combination of cement and fly ash. The expansive clay soil samples were first subjected to general classification tests where three classes of samples evolved; $12 \%$ cement optimal mix, $9 \%$ cement plus $3 \%$ fly ash optimal mix and the $0 \%$ (unstabilized) natural clay soil sample. The three different classes of samples were then subjected to engineering tests; Maximum Dry Densities (MDD), Optimum Moisture Contents (OMC), California Bearing Ratio (CBR), Unconfined Compression and the Undrained Triaxial test. The results showed that the soil sample stabilized with a mixture of $9 \%$ cement plus 3\% fly ash is better with respect to MDD, OMC, Bearing Capacity and Shearing Resistance, when compared with sample stabilized with $12 \%$ cement plus $0 \%$ fly ash. This shows that the addition of a certain percentage of fly ash will improve the stabilizing potential of cement on an expansive clay soil.

This research was centered on using a relatively new material (almond leaf ash) in combination with cement for stabilizaion purposes of lateritic soils. The aim of this research study was to determine the characteristics of almond leaves ash cement stabilized lateritic soil.

\section{MATERIALS AND METHODS}

\subsection{Research Design}

This research was directed towards determining the characteristics of almond leaves-ash cement stabilized lateritic soil and development of almond leaves-ash cement stabilized lateritic soil CBR model using the Scheffe's theory. Four basic materials were used in this study; Laterite, Almond leaf-ash, water and cement. In mix design, the Scheffe's $(4,2)$ simplex procedure was adopted. All materials used in this study were sourced within the Port Harcourt City environment. All tests carried out were done using standard experimental procedures. The CBR model was developed using results from the developed trial mixes and were subsequently validated using results from control mixes.

\subsection{Materials}

\subsection{Lateritic Soil}

Lateritic soil was obtained from a burrow pit located at the University of Port Harcourt, Rivers state. This unmodified soil sample was subjected to classification tests to properly grade the soil.

\subsubsection{Cement}

Dangote $3 \mathrm{X}$ cement was sourced from a local shop in Port Harcourt and used for the stabilization of the lateritic soil.

\subsubsection{Almond Leaf-Ash}

Almond leaves were sourced from an Almond tree in UNIPORT and was put in a desiccator to dry for 48 hours at a temperature of $200^{\circ} \mathrm{C}$. After drying it was subjected to a calcination temperature of $250^{\circ} \mathrm{C}$ for about 1 hour. After that, the resulting product was grounded into fine particles and passed through sieve no. 200.

\subsubsection{Water}

Potable water of suitable $\mathrm{pH}$ was sourced from the Asphalt Laboratory in UNIPORT for the essence of experiment. 


\subsection{Methods}

\subsubsection{Materials Classification}

\section{- Almond Leaf-Ash (ALA)}

The oxide composition of ALA was determined in a chemical laboratory in Port Harcourt. This substance was classified appropriately according to ASTM C618 [13].

\section{- Lateritic Soil}

The unmodified lateritic soil was subjected to preliminary tests such as; Atterberg's limits test, specific gravity test and hydrometer or sedimentation analysis tests and was thereafter, properly classified.

\subsubsection{Mix Design Development}

In developing the mix design for this study, the Scheffe's [14] simplex lattice principle was adopted. According to [15], a structural representation (shapes) of lines or planes joining assumed points of constituent materials of a mixture in which such points are equidistant from each other is referred to as a simplex. The Scheffe's theory makes use of Pseudo/theoretical components mix ratios. The Scheffe's $(4,2)$ simplex lattice theory was used in the development of the design matrix used for experimental procedures, where 4 represents the number of ALA- cement lateritic soil components and 2 represents the maximum number of material interaction. The materials used were; water, almond leaf-ash, cement and soil. According to Scheffe [14], the following laws must be obeyed in a simplex lattice structure;

- $X \neq$ negative; ( a pseudo mix ratio cannot be negative)

- $0 \leq X_{i} \leq 1$; ( the pseudo mix ratio at position i must be between 0 and 1$)$

- $\Sigma X_{i}=1 ;$ ( summation of all pseudo mix ratios must be equal to 1 )

Where, $X_{i}$ represents the pseudo component at the ith position of the lattice. For a $(q, m)$ component mixture, the number of points is given by $C_{m}\left(q^{+} m^{-1)}\right.$ (Scheffe [14]) which produced 10 design points for a four components, 2 maximum interactions mixture as given by Figure 1 .

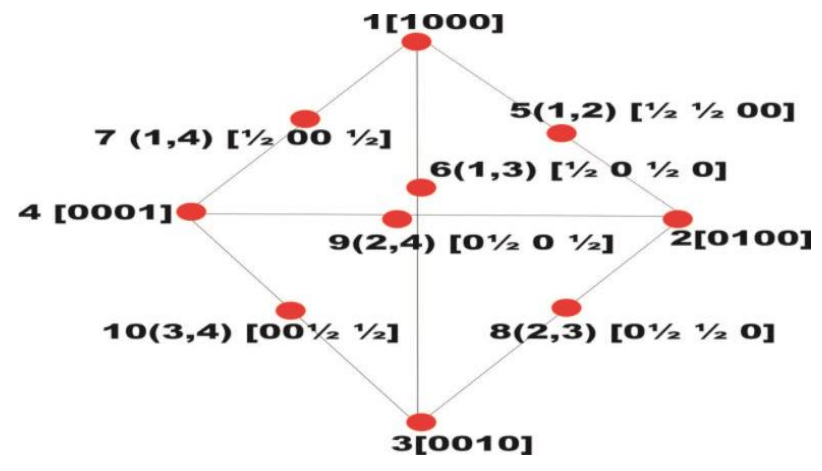

Fig. 1. $A(4,2)$ simplex lattice used in this study

With the laws laid out above, the actual or real mix ratios must be converted to theoretical or pseudo mix ratios. According to Scheffe [14], the pseudo mix ratio is related to the actual mix ratio by;

$$
\mathrm{Z}=[\mathrm{A}] \mathrm{X}
$$

Where:

$\mathrm{Z}=$ column matrix of real component ratio.

$X=$ column matrix of pseudo component ratio.

$[A]=$ coefficient matrix which is the transpose of the permutation matrix.

The permutation matrix was established from experience and intelligent guesses of ALA-cement lateritic soil mixes. The cement content in the mix was kept constant at $10 \%$ by weight of dry lateritic soil. The Almond leaf ash content varied between 2-20\% by weight of dry lateritic soil. The ratio of water in the mix varied between $0.1-0.25 \%$. For the vertices, where pure substances are assumed to exist, the mix ratios were obtained as; $(1,0.023,0.114,0.10),(1$, $0.125,0.125,0.15),(1,0.20,0.133,0.20)$ and $(1$, $0.286,0.143,0.25)$ for these points. In matrix form;

$$
[P]=\left[\begin{array}{llll}
1 & 0.023 & 0.114 & 0.10 \\
1 & 0.125 & 0.125 & 0.15 \\
1 & 0.200 & 0.133 & 0.20 \\
1 & 0.286 & 0.143 & 0.25
\end{array}\right]
$$

With the corresponding pseudo mix ratio being;

$$
[X]=\left[\begin{array}{llll}
1 & 0 & 0 & 0 \\
0 & 1 & 0 & 0 \\
0 & 0 & 1 & 0 \\
0 & 0 & 0 & 1
\end{array}\right]
$$

The transpose of matrix $[\mathrm{P}]$, becomes;

$$
[A]=\left[\begin{array}{cccc}
1 & 1 & 1 & 1 \\
0.023 & 0.125 & 0.20 & 0.286 \\
0.114 & 0.125 & 0.133 & 0.143 \\
0.100 & 0.150 & 0.200 & 0.250
\end{array}\right]
$$

Making $X$ subject of formula from Equation (1), yields Equation (5):

$$
X=[A]^{-1} Z
$$


Where: $[A]^{-1}=$ inverse of coefficient matrix.

With the aid of the transformation equations, pseudo components were being transformed to produce actual or real components shown in Table 1 and Table 2.

\subsubsection{Optimization Model Formulation and Coefficients Determination}

- Optimization Model Formulation

For a polynomial of q number variable and $\mathrm{m}$ degree, Equation (6) gives the general polynomial format;

$$
Y_{i \leq 1 \leq q}^{n}=b_{0}+\sum_{i \leq 1 \geq j \leq q} b_{i} X_{i}+\sum_{1 \leq 1 \leq j \leq q} b_{i j} X_{j} X_{i j}+\ldots \ldots \ldots .+\sum_{i j k}+\sum_{i l i 2 \ldots} \text { in } X_{i 1} X_{i 2} \ldots \ldots . . . X_{i n}
$$

Where; $1 \leq \mathrm{i} \leq \mathrm{q}, 1 \leq \mathrm{i} \leq \mathrm{j} \leq \mathrm{q}, 1 \leq \mathrm{i} \leq \mathrm{j} \leq \mathrm{k} \leq \mathrm{q}$ ， and $\mathrm{b}$ is the constant coefficient.

$\mathrm{X}$ is the pseudo component for constituents $\mathrm{i}, \mathrm{j}$, and $\mathrm{k}$ According to Scheffe [14], the condition in Equation (7) must be satisfied for a $(q, m)$ simplex structure $\sum_{i=1}^{q} x_{\mathrm{i}}=1$

For a $(q, m)$ polynomial of second degree form with four (4) number variables, Equations (7) and (6) become;

$$
\mathrm{X}_{1}+\mathrm{X}_{2}+\mathrm{X}_{3}+\mathrm{X}_{4}=1
$$

$\tilde{Y}=b_{0}+b_{1} X_{1}+b_{2} X_{2}+b_{3} X_{3}+b_{4} X_{4}+b_{12} X_{12} X_{2}+$ $b_{13} X_{1} X_{3}+b_{14} X_{1} X_{4}+b_{24} X_{2} X_{4}+b_{23} X_{2} X_{3}+b_{34} X_{3} X_{4}+$ $\mathrm{b}_{11} X_{1}^{2}+b_{22} X_{2}^{2}+b_{33}+b_{44} X_{4}^{2}$
Multiplying through Equation (8) by constant $b_{0}$, yields Equation (10).

$b_{0} X_{1}+b_{0} X_{2}+b_{0} X_{3}+b_{0} X_{4}=b_{0}$

Again, multiplying Equation (8) by $X_{1}, X_{2}, X_{3}$, and $X_{4}$ in succession and rearranging, Equation (11) is produced.

$X_{1}^{2}=X_{1}-X_{1} X_{2}-X_{1} X_{3}-X_{1} X_{4}$

$X_{2}^{2}=X_{2}-X_{1} X_{2}-X_{2} X_{3}-X_{2} X_{4}$

$X_{3}^{2}=X_{3}-X_{1} X_{3}-X_{2} X_{3}-X_{3} X_{4}$

$X_{4}^{2}=X_{4}-X_{1} X_{4}-X_{2} X_{4}-X_{3} X_{4}$

Substituting Equations (10) and (11) into Equation (9), Equation (12) was obtained after necessary transformation.

$\tilde{Y}=\left(b_{0}+b_{1}+b_{11}\right) X_{1}+\left(b_{0}+b_{2}+b_{22}\right) X_{2}+\left(b_{0}+\right.$ $\left.b_{3}+b_{33}\right) x_{3}+\left(b_{0}+b_{4}+b_{44}\right) x_{4}+\left(b_{12}-b_{11}-b_{22}\right)$ $x_{1} X_{2}+\left(b_{13}-b_{11}-b_{33}\right) x_{1} X_{3}+\left(b_{14}-b_{11}-b_{44}\right) X_{1} X_{4}+$ $\left(b_{23}-b_{22}-b_{33}\right) X_{2} X_{3}+\left(b_{24}-b_{22}-b_{44}\right) X_{2} X_{4}+\left(b_{34}-\right.$ $\left.b_{33}-b_{44}\right) X_{3} X_{4}$

Denoting; $B_{i}=b_{0}+b_{1}+b_{11}$ and $B_{i j}=b_{i j}-b_{i i}-b_{j j}$

The reduced second degree polynomial in 4 variables is shown by Equation (13).

$\tilde{Y}=B_{1} X_{1}+B_{2} X_{2}+B_{3} X_{3}+B_{4} X_{4}+B_{12} X_{1} X_{3}+B_{13} X_{1} X_{3}+$ $B_{14} X_{1} X_{4}+B_{23} X_{2} X_{3}+B_{24} X_{2} X_{4}+B_{34} X_{3} X_{4}$

Table 1. Mix Design for trial mixes.

\begin{tabular}{l|llll|llll}
\hline S/ & \multicolumn{3}{l}{ PSEUDO COMPONENTS RATIO } & & \multicolumn{4}{l}{ ACTUAL/ REAL COMPONENTS RATIO } \\
\cline { 2 - 8 } $\mathrm{N}$ & X1(water) & X2(cement) & X3(ALA) & X4(Soil) & Z1(water) & Z2(cement) & Z3(ALA) & Z4(Soil) \\
\hline 1 & 1 & 0 & 0 & 0 & 0.1 & 0.114 & 0.023 & 1 \\
2 & 0 & 1 & 0 & 0 & 0.15 & 0.125 & 0.125 & 1 \\
3 & 0 & 0 & 1 & 0 & 0.2 & 0.133 & 0.20 & 1 \\
4 & 0 & 0 & 0 & 1 & 0.25 & 0.143 & 0.286 & 1 \\
5 & 0.5 & 0.5 & 0 & 0 & 0.125 & 0.1195 & 0.074 & 1 \\
6 & 0.5 & 0 & 0.5 & 0 & 0.15 & 0.1235 & 0.1115 & 1 \\
7 & 0.5 & 0 & 0 & 0.5 & 0.175 & 0.1285 & 0.1545 & 1 \\
8 & 0 & 0.5 & 0.5 & 0 & 0.175 & 0.129 & 0.1625 & 1 \\
9 & 0 & 0.5 & 0 & 0.5 & 0.20 & 0.134 & 0.2055 & 1 \\
10 & 0 & 0 & 0.5 & 0.5 & 0.225 & 0.138 & 0.243 & 1 \\
\hline
\end{tabular}

Table 2. Mix Design for control mixes.

\begin{tabular}{l|llll|llll}
\hline $\mathrm{S} /$ & \multicolumn{4}{|l}{ PSEUDO COMPONENTS RATIO } & & \multicolumn{4}{l}{ ACTUAL/ REAL COMPONENTS RATIO } \\
\cline { 2 - 8 } $\mathrm{N}$ & $\mathrm{X}_{1}$ (Water) & $\mathrm{X}_{2}$ (cement) & $\mathrm{X}_{3}$ (ALA) & $\mathrm{X}_{4}$ (Soil) & $\mathrm{Z}_{1}$ (water) & $\mathrm{Z}_{2}$ (cement) & $\mathrm{Z}_{3}$ (ALA) & $\mathrm{Z}_{4}$ (Soil) \\
\hline 1 & 0.25 & 0.25 & 0.25 & 0.25 & 0.175 & 0.1288 & 0.1585 & 1 \\
2 & 0.20 & 0.20 & 0.30 & 0.30 & 0.185 & 0.1306 & 0.1754 & 1 \\
3 & 0.30 & 0.30 & 0.20 & 0.20 & 0.165 & 0.1269 & 0.1416 & 1 \\
4 & 0.20 & 0.20 & 0.20 & 0.40 & 0.19 & 0.1316 & 0.184 & 1 \\
5 & 0.10 & 0.30 & 0.30 & 0.30 & 0.19 & 0.1317 & 0.1856 & 1 \\
\hline
\end{tabular}


The number of coefficients has reduced from 15 in Equation (9) to 10 in Equation (13). Thus, the reduced second degree polynomial in q-variables is as shown by Equation (14).

$\tilde{Y}=\sum_{1 \leq i \leq q} B_{i} X_{i}+\sum_{1 \leq i \leq q} B_{i j} X_{i} X_{j}$

\section{- Model Coefficients Determination}

At the vertices of Figure 1 , pure substances are signified (Scheffe [14]). At any vertex, only one component of the mixture is represented while at boundary lines two components exist and the others are absent. Thus, the points $1,2,3$ and 4 were presented as having these coordinates; $[1,0,0,0],[0$, $1,0,0],[0,0,1,0]$ and $[0,0,0,1]$. Substituting the first four lattice coordinates into Equation (13) yields Equation (15)

$$
\begin{aligned}
& Y_{1}=B_{1} \\
& Y_{2}=B_{2} \\
& Y_{3}=B_{3} \\
& Y_{4}=B_{4}
\end{aligned}
$$

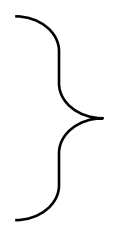

From Figure 1, Point 5 with coordinate $[1 / 2,1 / 2,0,0]$, Equation (16) can be deduced;

$$
\begin{aligned}
Y_{12} & =1 / 2 X_{1}+1 / 2 X_{2}+1 / 4 X_{1} X_{2} \\
= & 1 / 2 B_{1}+1 / 2 B_{2}+1 / 4 B_{12}
\end{aligned}
$$

$B_{i}=Y_{i}$, where $i=1,2,3, \ldots \ldots . . n$. Then substituting into Equation (15) yields:

$$
Y_{12}=(1 / 2) Y_{1}+(1 / 2) Y_{2}+(1 / 4) B_{12}
$$

Simplifying Equation (17), yields:

$B_{12}=4 Y_{12}-2 Y_{1}-2 Y_{2}$

Similarly, Equation (19) to Equation (21) can be developed. Thus:

$$
\begin{aligned}
& B_{13}=4 Y_{13}-2 Y_{1}-2 Y_{3} \\
& B_{14}=4 Y_{14}-2 Y_{1}-2 Y_{4} \\
& B_{23}=4 Y_{23}-2 Y_{2}-2 Y_{3}
\end{aligned}
$$

Generalizing, Equations (19) to (21), Equation (22) was formed.

$$
\begin{gathered}
B_{i}=Y_{i} \\
B_{i j}=4 Y_{i j}-2 Y_{i}-2 Y_{j}
\end{gathered}
$$

The above values become the coefficients of the $(4,2)$ second degree polynomial in Equation (13).

\subsubsection{Model Verification}

The CBR model developed were subjected to chisquare $\left(\chi^{2}\right)$ analysis at $5 \%$ level of significance for model verification test. The $\chi^{2}$ values were calculated in accordance to Equation (23).

$$
\mathrm{X}^{2}=\sum \frac{(\mathrm{O}-\mathrm{E})^{2}}{\mathrm{E}}
$$

Where; $\chi^{2}=$ chi-square,

$\mathrm{O}=$ experimental or observed value and

$\mathrm{E}=$ model or expected value.

\subsubsection{Experimental Procedure}

\section{- Specific Gravity Test}

The specific gravity of the unmodified lateritic soil was determined in accordance to ASTM D854 [16]. The specific gravity of the soil sample which is the ratio mass of the soil particle to the same (absolute) volume of the water was then determined using Equation (24).

$$
G s=\frac{w_{2}-w_{1}}{\left(w_{4}-w_{1}\right)-\left(w_{3}-w_{2}\right)}
$$

Where; $\mathrm{w}_{1}=$ weight of density bottle; $\mathrm{w}_{2}=$ weight of bottle plus dried soil; $w_{3}=$ weight of bottle plus soil plus water; $w_{4}=$ weight of bottle plus water

\section{- Sedimentation/Hydrometer Test}

This test was performed in accordance to ASTM D7928 [17]. Sedimentation is the process of allowing individual soil particles to settle down in the suspension and recording the observations (hydrometer and temperature readings) at regular intervals.

\section{- Atterberg's Limits Tests}

The Atterberg limit tests; liquid and plastic limit of the lateritic soil were determined according to ASTM D4318 [18]. The liquid limit is the limiting moisture content at which the cohesive soil passes from liquid state to plastic state. The plastic limit of a soil is the moisture content at which soil begins to behave as a plastic material.

\section{- CBR Tests}

The CBR test was performed in accordance to ASTM D1883 [19]. The test was carried out in a laboratory with air dried soil sample with a predetermined natural moisture contents. The CBR of a soil material is usually calculated at penetrations $2.5 \mathrm{~mm}$ and $5 \mathrm{~mm}$. Both values gotten will be compared and the higher one is usually selected. The readings were recorded and plotted. The CBR of the soil was then determined using Equations (25) and/or (26). 


$$
\begin{aligned}
& C B R=\frac{\text { Applied Force values at } 2.5 \mathrm{~mm}}{\text { Standard load }(13.24 \mathrm{KN})} \\
& C B R=\frac{\text { Applied Force values at } 5 \mathrm{~mm}}{\text { Standard load }(19.96 \mathrm{KN})}
\end{aligned}
$$

Where applied force is;

Applied force $=\frac{\text { plunger reading } x \text { proving ring factor }}{1000}$

\section{RESULTS AND DISCUSSION}

\subsection{Classification of Materials}

\subsubsection{Oxide Composition of Almond Leaf- Ash}

Table 3 shows the oxide composition of three oxides of almond leaf-ash at a calcination temperature of $250^{\circ} \mathrm{C}$ determined from the oxide composition test. These oxides represent the three most important oxides of a pozzolanic substance used for cement substitution purposes. Based on the results displayed in Table 3, ALA is a good pozzolanic substance possessing cementitious properties. According to ASTM C 618 [13], Pozzolans are divided into several classes; N class; Pozzolans derived from natural materials such as trass, clay, kaolin, F\&C class; Artificial pozzolan or manmade, including furnace slag, fly ash from coal combustion [20]. Almond Leaf-Ash was thus classified as $\mathrm{C}$ class pozzolan.

\subsubsection{Classification of Unmodified Soil}

Table 4 gives a summary of the properties of the unmodified lateritic soil. The specific gravity of the Lateritic soil was obtained as 2.27, Liquid Limit was found to be $25 \%$ and the Plastic limit was $15.76 \%$ giving rise to a Plasticity index of $9.24 \%$. A plasticity index value of $9.24 \%$ indicated that the lateritic soil is a plastic soil material with high clay content, this implies that the lateritic soil sample is not suitable for construction purposes.

Furthermore, the soil was classified based on the AASHTO soil classification system with the aid of result obtained from sieve analysis (Figure 2) as silty clay soil i.e. A-4 (4) soil. These kind of soil materials requires treatment before usage as road pavement materials.

\subsection{CBR of Cement Stabilized Lateritic Soil}

Figure 3 gives the Load Penetration Curve for the 10\% cement stabilized lateritic soil. The respective equations employed for calculation of CBR values at penetrations $2.5 \mathrm{~mm}$ and $5 \mathrm{~mm}$ are given in Equation (25) and Equation (26). The CBR of $10 \%$ Cement Stabilized Lateritic soil at $2.5 \mathrm{~mm}$ and $5 \mathrm{~mm}$ were calculated as $15.20 \%$ and $14.53 \%$ respectively. The higher value being that $2.5 \mathrm{~mm}$ penetration, $15.20 \%$ was taken as the CBR of the soil. According to British standard, the CBR standard for Laterite soil to be used for subgrades under Highway Engineering is between $5-15 \%$. Since CBR gotten is $15.20 \%$, it is therefore adequate for use as subgrade material.

\subsection{CBR of ALA-Cement Stabilized Lateritic Soil}

Table 5 shows the CBR values of ALA- cement stabilized lateritic soil for the trial mix design developed using Scheffe's theory. It can be observed that from the CBR values of $\mathrm{T} 1(17.00 \%), \mathrm{T} 2(17.60 \%)$, T3(27.56\%), T4(25.40\%), T5(15.71\%), T6(17.50\%), $\mathrm{T} 7(17.71 \%), \quad \mathrm{T} 8(18.04 \%), \quad \mathrm{T} 9(27.09 \%) \quad$ and $\mathrm{T} 10(26.87 \%)$ of Almond leaf-ash cement stabilized laterite, there's improvement in the soil strength as when compared to the CBR of $10 \%$ cement stabilized laterite(15.20\%). This shows that Almond Leaf-ash is a good modifier. All CBR values obtained from T1-T10 were greater than the $15.20 \%$ obtained for the cement stabilized lateritic soil.

Table 3. Oxide composition of Almond Leaf-Ash

\begin{tabular}{ll}
\hline Properties & Percentage (\%) \\
\hline $\mathrm{SiO} O_{2}$ & 62.7 \\
$\mathrm{CaO}$ & 8.3 \\
$\mathrm{Al}_{2} \mathrm{O}_{3}$ & 9.02 \\
\hline
\end{tabular}

Table 4. Unmodified Soil Properties

\begin{tabular}{ll}
\hline Properties & Value \\
\hline Specific Gravity & 2.27 \\
Liquid Limit & $25 \%$ \\
Plastic Limit & $15.76 \%$ \\
\hline
\end{tabular}




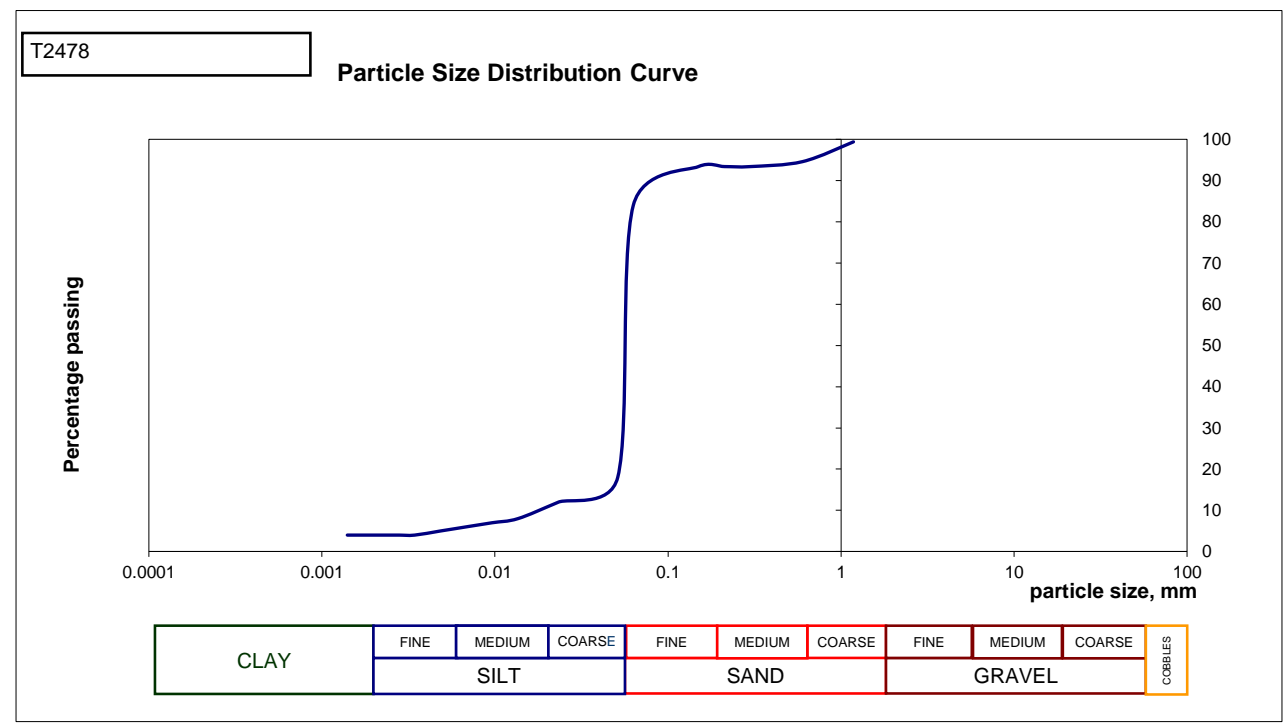

Figure 2. Sedimentation Analysis of Lateritic Soil

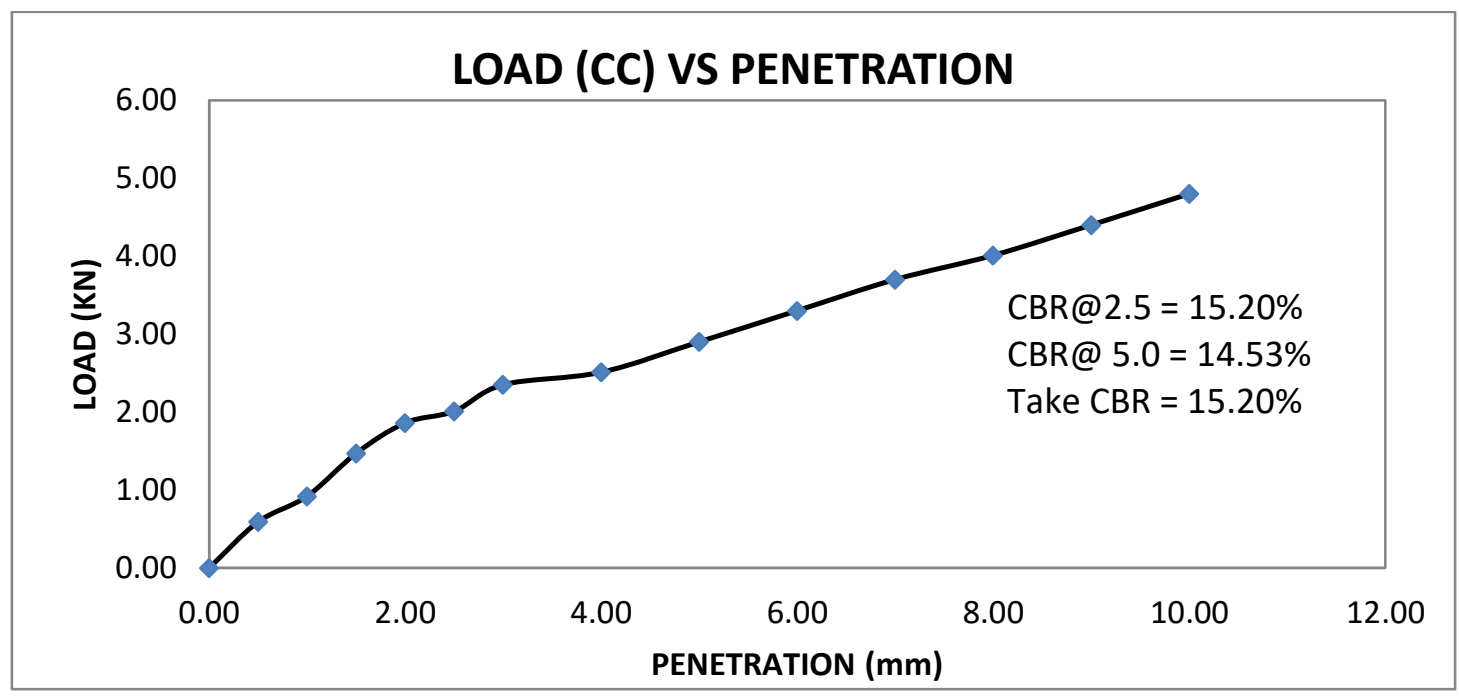

Figure 3. Load-Penetration Curve for 10\% Cement Stabilized Soil

Table 5. CBR Results for ALA-Cement Stabilized Soil

\begin{tabular}{l|llll|lllll}
\hline S/N & \multicolumn{3}{l}{ PSEUDO COMPONENTS RATIO } & \multicolumn{4}{l}{ ACTUAL/REAL COMPONENTS RATIO } & CBR (\%) \\
\cline { 2 - 9 } & $\mathrm{X}_{1}$ (water) & $\mathrm{X}_{2}$ (cement) & $\mathrm{X}_{3}$ (ALA) & $\mathrm{X}_{4}$ (Soil) & $\mathrm{Z}_{1}$ (water) & $\mathrm{Z}_{2}$ (cement) & $\mathrm{Z}_{3}$ (ALA) & $\mathrm{Z}_{4}$ (Soil) \\
\hline 1 & 1 & 0 & 0 & 0 & 0.1 & 0.114 & 0.023 & 1 & 17.00 \\
2 & 0 & 1 & 0 & 0 & 0.15 & 0.125 & 0.125 & 1 & 17.60 \\
3 & 0 & 0 & 1 & 0 & 0.2 & 0.133 & 0.20 & 1 & 27.56 \\
4 & 0 & 0 & 0 & 1 & 0.25 & 0.143 & 0.286 & 1 & 25.40 \\
5 & 0.5 & 0.5 & 0 & 0 & 0.125 & 0.1195 & 0.074 & 1 & 15.71 \\
6 & 0.5 & 0 & 0.5 & 0 & 0.15 & 0.1235 & 0.1115 & 1 & 17.50 \\
7 & 0.5 & 0 & 0 & 0.5 & 0.175 & 0.1285 & 0.1545 & 1 & 17.71 \\
8 & 0 & 0.5 & 0.5 & 0 & 0.175 & 0.129 & 0.1625 & 1 & 18.04 \\
9 & 0 & 0.5 & 0 & 0.5 & 0.20 & 0.134 & 0.2055 & 1 & 27.09 \\
10 & 0 & 0 & 0.5 & 0.5 & 0.225 & 0.138 & 0.243 & 1 & 26.87 \\
\hline
\end{tabular}

\subsection{ALA-Cement Stabilized Lateritic Soil CBR} Model

The results of the CBR values of trial mixes in Table 6 , were used in the formulation of the ALA-Cement
Stabilized lateritic soil CBR model. With the aid of data in Table 7 and Equation (22), the stability model coefficients for the CBR model for 4-2 polynomial was derived thus; 
$B_{1}=Y_{1}=17.00 \quad B_{13}=4 Y_{13}-2 Y_{1}-2 Y_{3}=-19.12$
$B_{2}=Y_{2}=17.60 \quad B_{14}=4 Y_{14}-2 Y_{1}-2 Y_{4}=-13.96$
$B_{3}=Y_{3}=27.56 \quad B_{23}=4 Y_{23}-2 Y_{2}-2 Y_{3}=-18.16$
$B_{4}=Y_{4}=25.40 \quad B_{24}=4 Y_{24}-2 Y_{2}-2 Y_{4}=22.36$
$B_{12}=4 Y_{12}-2 Y_{1}-2 Y_{2}=-6.36 \quad B_{34}=4 Y_{34}-2 Y_{3}-2 Y_{4}=1.56$
Substituting the above values into Equation $(13)$, the
optimization model for ALA-Cement soil CBR
becomes;
$\tilde{Y}=17.00 X_{1}+17.60 X_{2}+27.56 X_{3}+25.40 X_{4}-$
$6.36 X_{1} X_{2}-19.12 X_{1} X_{3}-13.96 X_{1} X_{4}-18.16 X_{2} X_{3}+$
$22.36 X_{2} X_{4}+1.56 X_{3} X_{4} \quad$ (28) Equation (28) represents the optimization model for predicting the CBR of ALA-Cement stabilized lateritic soil. This model can be used to predict the CBR of ALA-Cement stabilized lateritic soil of any arbitrarily given constituents ratio and vice versa.

\subsection{Model Verification}

The experimental and model values of CBR of ALACement stabilized soil shown in Table 7 for the control mixes were used in the verification of the developed model using the $\chi^{2}$ statistics. The $\chi^{2}$ statistics shown in Table 8 with a $\chi^{2}$ value of 0.145999 far less than $\chi^{2}$ value of 9.49 obtained from the standard chi-square table at $5 \%$ level of significance for a degree of freedom of (5$1=4)$, is an indication that the model CBR values are close to the experimental CBR values revealing that the model can be relied upon in predicting the CBR of ALA-Cement stabilized lateritic soil.

\section{CONCLUSION AND RECOMMENDATIONS}

\subsection{Conclusion}

The following conclusions can be drawn from the study.

- Judging from the Plastic Limit (15.76\%), Liquid Limit $(25.00 \%)$ and Plasticity index $(9.24 \%)$, the soil is poor and not suitable for construction purposes.

Table 6. Stability Test Result for Trial Points

\begin{tabular}{|c|c|c|c|c|c|c|}
\hline \multirow{2}{*}{$\mathrm{S} / \mathrm{N}$} & \multicolumn{4}{|c|}{ CBR TEST RESULTS } & \multirow[t]{2}{*}{ Response Symbol } & \multirow[t]{2}{*}{ CBR (\%) } \\
\hline & $\mathrm{Z}_{1}$ (water) & $\mathrm{Z}_{2}$ (cement) & $\mathrm{Z}_{3}(\mathrm{ALA})$ & $\mathrm{Z}_{4}$ (Soil) & & \\
\hline 1 & 0.1 & 0.114 & 0.023 & 1 & $\mathrm{Y}_{1}$ & 17.00 \\
\hline 2 & 0.15 & 0.125 & 0.125 & 1 & $Y_{2}$ & 17.60 \\
\hline 3 & 0.2 & 0.133 & 0.20 & 1 & $Y_{3}$ & 27.56 \\
\hline 4 & 0.25 & 0.143 & 0.286 & 1 & $\mathrm{Y}_{4}$ & 25.40 \\
\hline 5 & 0.125 & 0.1195 & 0.074 & 1 & $Y_{12}$ & 15.71 \\
\hline 6 & 0.15 & 0.1235 & 0.1115 & 1 & $Y_{13}$ & 17.50 \\
\hline 7 & 0.175 & 0.1285 & 0.1545 & 1 & $Y_{14}$ & 17.71 \\
\hline 8 & 0.175 & 0.129 & 0.1625 & 1 & $Y_{23}$ & 18.04 \\
\hline 9 & 0.20 & 0.134 & 0.2055 & 1 & $Y_{24}$ & 27.09 \\
\hline 10 & 0.225 & 0.138 & 0.243 & 1 & $Y_{34}$ & 26.87 \\
\hline
\end{tabular}

Table 7. CBR Results for Control Mixes

\begin{tabular}{lllllll}
\hline S/N & \multicolumn{3}{l}{ ACTUAL/ REAL COMPONENTS RATIO } & \multicolumn{3}{l}{ CBR Results (\%) } \\
\cline { 2 - 7 } & $Z_{1}$ (water) & $Z_{2}$ (cement) & $Z_{3}($ ALA $)$ & $Z_{4}$ (Soil) & Exp. Values & Model Values \\
\hline 1 & 0.175 & 0.1288 & 0.1585 & 1 & 20.54 & 20.320 \\
2 & 0.185 & 0.1306 & 0.1754 & 1 & 19.92 & 21.603 \\
3 & 0.165 & 0.1269 & 0.1416 & 1 & 19.26 & 19.157 \\
4 & 0.19 & 0.1316 & 0.184 & 1 & 22.86 & 22.499 \\
5 & 0.19 & 0.1317 & 0.1856 & 1 & 22.47 & 22.845 \\
\hline
\end{tabular}

Table 8. Chi-Square Statistics

\begin{tabular}{llll}
\hline Exp.(Observed,O) Values & Model (Expected, E) Values & $(\mathrm{O}-\mathrm{E})^{2}$ & $(\mathrm{O}-\mathrm{E})^{2} / \mathrm{E}$ \\
\hline 20.54 & 20.32 & 0.0484 & 0.002382 \\
19.92 & 21.603 & 2.832489 & 0.131116 \\
19.26 & 19.157 & 0.010609 & 0.000554 \\
22.86 & 22.499 & 0.130321 & 0.005792 \\
22.47 & 22.845 & 0.140625 & 0.006156 \\
\hline & & $\mathrm{X}^{2}$ & 0.145999 \\
\cline { 2 - 3 }
\end{tabular}


- Almond leaf-ash can be used for soil stabilization even where high subgrade performance is necessary.

- The model developed for the CBR of ALACement stabilized lateritic soil proved adequate from the $\mathrm{R}^{2}$ statistics conducted. This model can be adopted in predicting/optimizing the CBR of lateritic soil stabilized with ALA and cement.

\subsection{Recommendations}

A Computer Programme should be written based on the model developed to hasten the optimization process for CBR of ALA-Cement stabilized lateritic soil.

\section{REFERENCES}

[1] Ola, S. (1978). Geotechnical properties and behaviour of some Nigerian lateritic soils in: Tropical soils of Nigeria in Engineering practice. Rotterdam: A.A. Balkema.

[2] Nnochiri, E., \& Aderinlewo, O. (2016). Geotechnical Properties of Lateritic Soil Stabilized with the Ashes of Oil Palm Fonds. The civil engineering journal, 22(4), 1-9.

[3] Alhassan, M. (2008). Permeability of Lateritic Soil Treated with Lime and Rice Husk Ash. AUJ.T, 12(2), 115-120.

[4] Bello, A., I. J., \& Hammed, A. (2015). Stabilization of lateritic soil with cassava peels ash. British Journal of Applied Science and Technology, 7(6), 642-650.

[5] Okeiyi, A. A. (2017). Use of Quick and Hydrated Lime in Stabilization of Lateritic Soil: Comparative Analysis of Data. International Journal of Geo-engineering, 1-13.

[6] Haldankar, S., Manna, A., Krithesh, \& Lewis, P. (2016). improvement of lateritic soil using eggshell powder and marble dust and its comparison with lime stabilized clay. International journal of advances in mechanical and civil engineering, Special issue, 28-30.

[7] Ayininuola, G., \& Abidoye, S. (2018). Soil stabilization using Bitumen Emulsion and
Cement combination as additives. Journal of Earth Science and Engineering, 8, 66-74.

[8] Houben, H., \& Guillaud, H. (1994). Earth Construction. $A$ Comprehensive Guide Intermediate Technology Publications, 73.

[9] Stulz, R., \& Mukerji, K. (1993). Appropriate Building Materials. Catalogue of Potential Solution, 29.

[10] Okonkwo, U., Agunwamba, J., \& Iro, U. (2016). Geometric Models for Lateritic Soil Stabilized with Cement and Bagasse Ash. Nigerian Journal of Technology, Vol. 35, No. 4, 769-777.

[11] Musa, A., \& Mustapha, A. M. (2017). Academic direct. Retrieved may 22, 2019, from Academic direct: http://lejpt.academicdirect.org.

[12] Amu, O., Fajobi, A., \& Afekhuai, S. (2005). Stabilizing potential of Cement and Fly Ash Mixture on Expansive Clay Soil. Journal of Applied Science Vol. 5, 1669-1673.

[13] Scheffe, H. (1958). Experiments with Mixtures. Journal of the Royal statistical society.

[14] ASTM C618 (2008). Classification of Pozzolanic Materias. American Society for Testing and Materials, West Coshohocken, USA. ASTM C618.

[15] Jackson, N. (1983). Civil Engineering Materials, RDC. Arter Ltd, Hong Kong

[16] ASTM D854 (2000). Standard Test Methods for Specific Gravity of Soil Solids by Water Pycnometer, USA. ASTM D854.

[17] ASTM D7928 (2017). Standard Test Method for Particle-Size Distribution (Gradation) of FineGrained Soils Using the Sedimentation (Hydrometer) Analysis. USA, ASTM D7928.

[18] ASTM D4318 (2008). Standard Test Method for Atterberg Limit Test Analysis. USA, ASTM D4318.

[19] ASTM D1883 (2005). Standard Test Method for CBR (California Bearing Ratio) of LaboratoryCompacted Soils. USA, ASTM D1883.

[20] Nelson, E. (1990). Cement Additives and mechanisms of action in well cementing. Texas: 5000 gull freeway Houston 